\title{
FOOD SAFETY ASPECT OF INSECTS: A REVIEW
}

\author{
M. MÉZES* \\ Department of Nutrition, Szent István University, Páter K. u. 1, H-2103 Gödöllő. Hungary
}

(Received: 8 May 2018; accepted: 26 July 2018)

\begin{abstract}
Insects are alternative protein sources as nutritious novel food. However, there are some risks associated with the consumption of insects, even if rearing in controlled systems. Except for a recent EFSA opinion on the safety of insects as food, the European law is not conclusive regarding using insects as food products. Insects may be associated with microorganisms, but the prevalence of pathogens is usually lower than in case of other animal proteins. Insect proteins can induce allergic reactions, but only few studies are available on allergic reactions due to insect ingestion, and direct hypersensitivity to insect protein has not been proven. Some insect species are considered toxic, because some toxic substances are accumulated from toxic plants or are synthesized by the insects. However, there are few reports available about adverse reactions caused by insect consumption. Insects and insect derived food products may contain hazardous chemicals such as heavy metals, dioxins, mycotoxins, plant toxins, biocides, and veterinary drugs. However, data on hazardous chemicals in reared insects and accumulation of chemical contaminants from the substrates are limited. This review is not demonstrating the safety of insects as a food category, but the possibility of insects for human consumption with no more hazards than other animal products.
\end{abstract}

Keywords: edible insects, microbial safety, chemical safety, allergenic protein

There is discussion about the insects as potentially sustainable protein source for the rapidly growing world population. The future demand for food and animal-derived protein will require environmentally friendly, novel food sources. Insects are one of such novel food sources, but there are some risks associated with the production, processing, and consumption of insects.

The beneficial nutritive effects of insect proteins are well known, and it has a long tradition in human history as food, which dates back to prehistoric times (TOMMASEOPonzetTA, 2005). The first document about insect as human food dates back to the eighth century BC in the Middle East (BoDENHEIMER, 1951). However, more exploration is needed to decide which insect species are suitable for intensive farming; also researches are required about the processing, safety, and regulation of insects as human food (Fellows, 2014). Total number of edible insects around the world is not exactly known, the estimations are increasing with time from 1000 (DeFoliart, 1997), 1681 (Ramos-Elorduy, 2005) up to 1900 (Jongema, 2012).

According to a global estimation (van Huis et al., 2013), the most commonly consumed insects of humans are beetles (31\%), caterpillars (18\%), and bees, wasps, and ants (14\%). Consumption of grasshoppers, locusts, and crickets are about $13 \%$, followed by cicadas,

\footnotetext{
* To whom correspondence should be addressed.

Phone: +36-28410735; fax: +36-28410804; e-mail: Mezes.Miklos@mkk.szie.hu
}

This is an open-access article distributed under the terms of the Creative Commons Attribution-NonCommercial 4.0 International License (https://creativecommons.org/licenses/by-nc/4.0/), which permits unrestricted use, distribution, and reproduction in any medium for non-commercial purposes, provided the original author and source are credited, a link to the CC License is provided, and changes - if any - are indicated.

0139-3006 (C) 2018 The Author(s) 
leafhoppers, plant hoppers, scale insects, and true bugs $(10 \%)$, termites $(3 \%)$, dragonflies $(3 \%)$, flies $(2 \%)$, and others $(5 \%)$.

However, hazards associated some possible food safety with the use insects or insect proteins. These hazards include different contaminants, such as heavy metals, mycotoxins, pesticide residues, antinutritive factors, and pathogens (van HuIs et al., 2013). The European Food Safety Authority has published an initial risk assessment for using insects as a source of protein for human consumption (EFSA, 2015). It concluded that the possible presence of biological and chemical hazards in food products derived from insects depends on the method of production, the substrate (feed) of insects, the insect species, the stage of lifecycle at harvesting, and the method of further processing. According to a recent review, there is a lack of scientifically based knowledge of insect processing to ensure food safety, especially when these processes are carried out on an industrial scale (SCHLÜTER et al., 2017).

The presence of parasites could also be a food safety problem in case of consumption of edible insects as food. Additionally, some insects also have mechanical risk for consumers, because hooks of their legs could cause damages in the digestive tract, which can be eliminated by removing certain parts of their bodies before consuming.

\section{Nutritive value of insects}

Insects are nutritious foods (RUMPOLD \& SCHLÜTER, 2013) because of their high (20 to $76 \%$ of dry matter) and valuable protein content, but it is highly variable because of the wide variety of species, and its value also differs depending on the metamorphic state of the insect. Insect proteins contain measurable amount of essential amino acids such as tryptophan, lysine, and histidine (Collavo et al., 2005). Insect proteins are highly digestible (77-98\%), although the exoskeleton - due to the presence of chitin - is lowering it (RAmos-ElorduY et al., 1997). Fat content is also variable ( $2-50 \%$ of dry matter), with different fatty acid content, such as palmitic acid (8-38\%), oleic acid (9-48\%), and up to 70\% unsaturated fatty acids (DEFoliarT, 1992). Carbohydrate content (2.7 to $49.8 \mathrm{mg}$ per $\mathrm{kg}$ fresh matter) is mainly chitin, the main component of the exoskeleton. Chitin is largely believed to be indigestible by humans, although chitinase has been found in human gastric juices (PAOLETTI et al., 2007). Otherwise, chitin acts like a dietetic fibre (Muzzarelli et al., 2001), and this could imply a high fibre content in edible insects. Insects also contain trace elements (copper, iron, manganese, selenium, and zinc) and vitamins (riboflavin, pantothenic acid, biotin, and, in some cases, folic acid). However, trace element and vitamin contents of insects change seasonally and depend on the feed (ADÁmkovÁ et al., 2017). Preparation and processing methods (e.g. drying, boiling, or frying) applied before consumption will also influence the nutritional composition. A few scattered studies analyse the nutritional value of edible insects; however, these data are not always comparable due to the variations between insects and because of the varying methodologies employed to analyse the compounds (FAO, 2012). Moreover, where commonly consumed, insects comprise only a part of local diets.

\section{Food safety regulations of insects}

Studies on food safety of insects are limited, and some safe insects may be unhealthy if they contain allergens or are fed with plants originated from a polluted area. There is a long-term 
tradition of using insects as food outside the EU, where the use of insects for human food is, in practice, more tolerated than regulated. Otherwise, it is generally accepted as adequate evidence that insect food is safe for human consumption (DEFoliART, 1992), and it is estimated that at least 2 billion people worldwide practise insect eating regularly. Although it has been stated that no significant health problems have arisen from the consumption of edible insects (BANJO et al., 2006), consumer confidence is arguably strongly correlated with the perceived safety of a given product. However, many low-income countries do not have policies controlling the use of agro-chemicals in areas where people collect edible insects, and the consumers have little or no knowledge about the potential consequences of eating chemically treated insects (KINYURU et al., 2012).

There is a regulation in the EU (2015/2283/EU) about the insects as novel food (EU, 2015), which is partly based on a recent EFSA Opinion about the safety of insect as food (EFSA, 2015). The regulation specifies those insects, which can be use as novel food, but other insect species might also be used as food in EU countries (SCHLÜTER et al., 2017). The EU regulated the introduction of animal origin materials into the food chain, which can also be used for insects, and it should comply with Annexes I and II of Regulation 852/2004/EC (EU, 2004a). Otherwise, the whole process of insect protein production should comply with the Food Hygiene Regulations (852/2004/EC and 853/2004/EC) (EU, 2004a,b). To date, European law is not conclusive on several issues regarding the use of novel protein sources, such as insects, in food products (Belluco et al., 2013). Additionally, processing, storage, and transport of insects also need several special requirements for keeping the food safety criteria (SCHABEL, 2008). Recently, the EU regulated (2017/893/EU) the provisions for general criteria of insect and insect protein production, with particular attention to materials used for feeding the insects and their larvae (EU, 2017).

Consumption of insects has a long-term tradition outside the EU; therefore, insects are identified as traditional food from third countries.

\section{Microbial safety}

Insects may have associated microorganisms that can influence their safety as food. The presence of pathogenic bacteria is influenced by the hygienic conditions of the substrate and the environment, namely rearing conditions. Both insects collected in nature or raised on farms may be infected with pathogenic microorganisms, such as bacteria (Staphylococcus, Bacillus, Campylobacter, Pseudomonas, Micrococcus, Acinetobacter, Proteus, Escherichia, Enterobacteriaceae, and other spore-forming bacteria), also virus, fungi, and protozoa (KLunder et al., 2012; VeGA \& KaYA, 2012). The prevalence of these pathogens is usually lower than in other non-processed animal protein sources, since no active replication of the pathogens occur in the intestinal tract of insects, as it was proven for Campylobacter jejuni (HAzeleger et al., 2008). Transmission of prions through edible insects has not been proven yet, only some ectoparasites, such as Hypoderma bovis and Oestrus ovis, were found as possible transmission factors (LuPI, 2006). Furthermore, the risk of transmission of these bacteria could be mitigated through effective processing.

A study on four commercial insect species (Zoophobas morio, Tenebrio molitor, Galleria mellonella and Acheta domesticus) showed a high total microbial charge ( $10^{5}$ to $\left.10^{6} \mathrm{CFU} \mathrm{g}^{-1}\right)$ on samples originating from a closed-cycle farm. It was mainly composed of Gram-positive bacteria, as faecal and total coliforms. The Gram-positive population was mostly formed by 
Micrococcus spp., Lactobacillus spp. $\left(10^{5} \mathrm{CFU} \mathrm{g}^{-1}\right)$, and Staphylococcus spp. (approximately $\left.10^{3} \mathrm{CFU} \mathrm{g}^{-1}\right)$. However, Salmonella spp. and Listeria monocytogenes were not isolated from the tested samples (GiACCONE, 2005).

Insect pathogens are taxonomically different from vertebrate pathogens and can be regarded as harmless to humans. Insects also have associated microorganisms in their gut flora, but these organisms cannot be regarded as potential human pathogens (van Huis et al., 2013). Spores of various microorganisms may be present on insect cuticles, including those microorganisms that grow saprotrophically on edible insect products. Insects are taxonomically distant from humans; therefore, the risk of zoonotic infections is expected to be low. Nevertheless, insects can be potential vectors of medically relevant pathogens. The risk of zoonotic infections (transmitting diseases from humans to animals and back) could rise with the careless use of waste products, the unhygienic handling, and direct contact between farmed insects and insects outside the farm due to weak biosecurity (EFSA, 2012).

Insect farming can provide a control over hygienic practices and safe feed sources for insects, mitigating potential microbiological hazards. The importance of hygienic handling and correct storage was investigated in laboratory experiments (KLUNDER et al., 2012). The microbiological content of farmed yellow mealworm larvae (Tenebrio molitor) and house crickets (Acheta domesticus) can be partly eliminated by boiling the insects in water for a few minutes, but the spores were found to survive this process, with the potential that the spores could germinate and the bacteria can grow under favourable conditions. Such spore-forming bacteria were found in the gut and on the skin of insects. Roasting alone did not kill all Enterobacteriaceae; therefore, a few minutes of boiling is suggested before roasting. Alternative preservation techniques are drying and acidifying. Lactic fermentation resulted in successful acidification, and it was demonstrated to be effective in safeguarding shelf life and safety by the control of enterobacteria and bacterial spores (KLUNDER et al., 2012).

In contrast to being a potential microbial hazard, some edible insects are known to contain antibacterial peptides. Those peptides have been found to inhibit strains of food pathogens such as Escherichia coli, Pseudomonas aeruginosa, Salmonella typhimurium, Shigella dysenteriae, Staphylococcus aureus, and Bacillus subtilis (Yi et al., 2014).

\section{Moulds and mycotoxins}

Drying of insects limits the growth of most microorganisms, but in humid areas, dried insects are susceptible to moisture pick-up, which can enable mould growth, therefore additional heating stage is required before consumption (AMADI et al., 2005). Although approximately 1000 species of the fungal phyla are known to infect and kill insects (VEGA et al., 2012), only very few of them produce mycotoxins. Heat treatment is useful against moulds, but cannot eliminate mycotoxins, because of their extreme heat stability (Bullerman \& BianchinI, 2007). Information is scarce on the mycotoxin contamination of edible insects. Aspergillus mould infection and aflatoxin contamination were checked by MPUCHANE and co-workers (1996) in edible grasshopper (Imbrasia belina), and the level of total aflatoxins varied from $0-50 \mu \mathrm{g}$ per $\mathrm{kg}$ of product. The maximum safe level of total aflatoxins set by EU is $10-15 \mu \mathrm{g}$ per kg for foodstuffs of plant origin, but there is no regulation for foodstuffs of animal origin, including insects (EC 1991/2006). However, frequent consumption of contaminated foods over longer periods is likely to pose health risks. 


\section{Parasites}

Parasites also represent a potential hazard in relation to insect consumption. Metacercariae were found as cause of fluke in insects consumed in Southeast Asia (CHAI et al., 2009). Plagiorchid parasites were reported as a new parasite species in humans probably originating from eating insect larvae (CHAI et al., 2009). Nematode parasite Gongylonema pulchrum cases have been reported in humans in many places around the world (MolAvi et al., 2006), because the intermediate hosts of this parasite are cockroaches. Myiasis is the infestation of humans with dipterous larvae, which occurs when fly eggs reach the gastrointestinal tract, but common housefly is rarely reported as the cause of myiasis. Among edible insects, Hermetia illucens can be a potential vector (SEHGAL et al., 2002). Insects can also be potential biological vectors of trypanosomiasis, which infected about 10 million people worldwide (WHO, 2010). Some cases have been reported linking the infection with the ingestion of insects (PEREIRA et al., 2010).

Among other potential foodborne pathogens, Entamoeba histolytica and Giardia lamblia have been isolated in cockroaches. Cryptosporidium parvum has also been found in insects, which is lethal for immunocompromised individuals (GRACZYK et al., 2005). These parasites could be present also in edible insects, and should be considered in the case of insect consumption as food.

\section{Allergic reactions to edible insects}

Like most protein-containing foods, arthropods can induce IgE-mediated allergic reactions in sensitive humans (MitsuHashi, 2008). These allergens may cause eczema, dermatitis, rhinitis, conjunctivitis, congestion, angioedema, and bronchial asthma. While some people have a history of atopy (allergic hypersensitivity), it is also possible to develop allergic sensitivity through long-term exposure. The majority of cases are inhalant or contactant in nature (Phillips \& Burkholder, 1995; Barletta \& Pini, 2003). Tropomyosins from cockroaches, mites, and shrimps have been reported to be allergenic (REese et al., 1999). The findings suggest that people with seafood allergy also have allergic reactions in case of consuming edible insects (REESE et al., 1999). However, few studies have been published on allergic reactions due to insect ingestion, and they did not prove the direct hypersensitivity to insect protein. Therefore, the risk of food allergy associated with insect consumption needs further investigation, and greater attention is required in distinguishing between toxic and allergic symptoms (LeE et al., 1999; Pitetti et al., 1999). The processing, such as boiling, has doubtful effect on destroying the allergenic components (Phillips \& BurKholder, 1995). For those people, who have no history of arthropod or insect allergen sensitivity, usually have no acquired sensitivity for allergic reactions, even if they eat and/or are exposed to insects through long-term exposure in sufficient quantities.

\subsection{Immunological effects of chitin, a major component in insect cuticle}

Chitin and its derivatives have anti-viral and anti-tumour activities, and its effects on innate and adaptive immune response effects in insects have only recently been recognized (LEE et al., 2008b). It was suggested that chitin is an allergen (MuzzAreLli et al., 2001), however, chitin induces non-specific host resistance against infections by pathogenic bacteria and 
viruses in vertebrates, and there are indications that chitin reduces allergic responses (LeE et al., 2008a).

\section{Toxicity}

Some insect species are considered toxic, therefore precautionary measures are taken. A part of toxic substances is accumulated in insects after consumption of toxic plants, but the insects synthesize other toxic substances as well. However, there are only few reports available on adverse reactions caused by insect consumption. For instance, cases of ataxia syndrome, characterized by tremors, ataxia and, varying levels of impaired consciousness, were reported after consumption of the seasonal silkworm (Anaphe venata) in southwest Nigeria, possibly due to its thiaminase activity and consequently thiamine deficiency (АDAMOLEKun et al., 1997). Metabolic steroids, including testosterone and dihydrotestosterone, were found in beetles (Dytiscidae family), which may cause growth retardation, hypofertility, masculinisation in females, oedema, jaundice, and liver cancer in human. Cyanogenic substances, such as cyanogenic glycosides and hydroxynitrils, can also be present in insects (Coleoptera and Lepidoptera), causing inhibition of succinate dehydrogenase and carbonic anhydrase and inhibiting oxidative phosphorylation (NAHRSTEDT, 1988).

\section{Contamination with metals and organic pollutants of the environment}

Insect derived food products may contain hazardous chemicals, e.g. heavy metals, dioxins, pesticides, and veterinary drugs. However, published data on hazardous chemicals in reared insects as well as data on accumulation/excretion of chemical contaminants from the substrates are very limited.

Heavy metals are not a negligible problem as they can be bio-accumulated in insect bodies. Harmful metals from the environment have been found in the insects, such as in the fat, exoskeleton, reproductive organs, and digestive tracts, where they accumulate. A study on the yellow mealworm (Tenebrio molitor) and black soldier fly (Hermetia illucens) larvae showed that the insects accumulate cadmium, lead, and arsenic when they feed on contaminated substrates, such as organic matter in soils that contain these metals (VIJVER et al., 2003), or from a herbicide, sodium-methyl arsenate (vAN DER Fels-KLERX et al., 2016). High lead content was found in dried grasshopper, and the dehydration resulted increase of lead concentration (HANDLEY et al., 2007). Extreme accumulation of selenium was found in Tenebrio molitor larvae (Hogan \& RAZniak, 1991).

Pesticides used against invading insects are potentially dangerous for consumers, particularly if the insects and insect products have been obtained by wild harvesting rather than controlled farming. It is a real problem in some developing countries, where edible, even dead insects, mainly locusts and grasshoppers, are collected and consumed after insecticide treatment. According to a study in Kuwait, the captured locusts contained no chlorinated pesticides, but a relatively high amount of organophosphorus pesticides was found, possibly due to the pesticides that were used in that area (SAEED et al., 1993). However, in case of pesticide treatment, only about less than $0.1 \%$ of pesticides applied reaches their target pests, the remaining $99.9 \%$ moves into the environment and may accumulate in the beneficial biota, soil and water, therefore can accumulate in edible insects through the substrate used for feeding (Pimentel, 1995). 
The presence of benzoquinone in insects was also demonstrated (Brown et al., 1992), which is widely distributed in plants, and accumulates in insects, in particular Tenebrionidae species (CRESPO et al., 2011). Ingestion of this kind of insects can be cytotoxic in humans, but International Agency for Research on Cancer (IARC) officially states that no epidemiological data are available on the carcinogenicity of 1,4-benzoquinone, and classified 1,4-benzoquinone as potentially not carcinogenic to humans (Group 3; IARC, 1999).

Processing of insects also arises formation of potentially toxic compounds, like heterocyclic aromatic amines, such as acrylamide or furan, and other compounds, such as chloropropanol, due to heat treatment (IARC, 1993), but there are no data available on their content in edible insects.

\section{Conclusions}

Insect consumption by humans has always been a worldwide practice, especially in those countries, where food is in short supply and food safety is not a concern. The nutritional value of insects is comparable to that of other animal protein sources, such as crustaceans, fish, and meat. Insects have high quality protein content due to the presence of all the essential amino acids in the recommended ratios. Additional value of insects is their fatty acid composition, which is within the suggested range for health purposes. Moreover, insects might be important fibre sources.

Concerning hazards, insects, like other foodstuffs, may cause allergic symptoms (FDA, 1995). Some insect allergens have common cross-reactivity, for example, insects and crustaceans. From a microbiological point of view, insects can harbour different kinds of food pathogenic bacteria, but a properly managed insect farm could remain free from pathogens. The possibility for insects to harbour parasites has also been described, but this risk can be reduced, since parasites are strictly connected to environmental features. Chemical risks can be reduced by avoiding consumption of those insects, which synthetize poisons and reduce the chemical bioaccumulation by a controlled feeding program, to minimise the feed contamination by chemicals.

This review demonstrates the possibility for humans to consume edible insect species with no more hazards than other animal products. Insects can be regarded as safe, if properly managed and consumed.

The publication is supported by the EFOP-3.6.3-VEKOP-16-2017-00008 project. The project is co-financed by the European Union and the European Social Fund.

\section{References}

AdÁmková, A., Mlček, J., Kouřimská, L., Borkovcová, M., Bušina, T., Adámek, M., BednáŘová, M. \& Krajsa, J. (2017): Nutritional potential of selected insect species reared on the Island of Sumatra. Int. J. Env. Res. Pub. He., 14, 521.

Adamolekun, B., McCandless, D.W. \& Butterworth, R.F. (1997): Epidemic of seasonal ataxia in Nigeria following ingestion of the African silkworm Anaphe venata: Role of thiamine deficiency? Metab. Brain Dis., 12, 251258.

Amadi, E.N., Ogbalu, O.K., Barimalaa, I.S. \& Pius, M. (2005): Microbiology and nutritional composition of an edible insect (Bunaea alcinoe Stoll) of the Niger Delta. J. Food Safety 25, 193-197. 
Banjo, A.D., Lawal, O.A. \& Songonuga, E.A. (2006): The nutritional value of fourteen species of edible insects in southwestern Nigeria. Afr. J. Biotechnol., 5, 298-301.

Barletta, B. \& Pin, C. (2003): Does occupational exposure to insects lead to species-specific sensitization? Allergy, $58,868-870$.

Belluco, S., Losasso, C., Maggioletti, M., Alonzi, C.C., Paoletti, M.G. \& Ricci, A. (2013): Edible insects in a food safety and nutritional perspective: A critical review. Compr. Rev. Food Sci. Food Saf., 12, 296-313.

Bodenheimer, F.S. (1951): Insects as human food; A chapter of the ecology of man. Dr. W. Junk Publishers, The Hague. pp. 39-69.

Brown, W., Doyen, J., Moore, B. \& Lawrence, J. (1992): Chemical composition and taxonomic significance of defensive secretions of some Australian Tenebrionidae (Coleoptera). Aust. J. Entomol., 31, 79-89.

Bullerman, L.B. \& Bianchin, A. (2007): Stability of mycotoxins during food processing. Int. J. Food Microbiol., $119,140-146$

Chai, J.Y., Shin, E.H., Lee, S.H. \& Rim, H.J. (2009): Foodborne intestinal flukes in Southeast Asia. Korean J. Parasitol., 47, S69-S102.

Collavo, A., Glew, R.H., Yunk-Sheng, H., Lu-Te, C., Bosse, R. \& Paoletti, M.G. (2005): Housekricket smallscale farming. -in: Paoletti, M.G. (Ed.): Ecological implications of minilivestock: Potential of insects, rodents, frogs and snails. Science Publishers, Enfield. pp. 519-544.

Crespo, R., Villaverde, M.L., Girotti, J.R., Guerci, A., Juarez, M.P. \& de Bravo, M.G. (2011): Cytotoxic and genotoxic effects of defence secretion of Ulomoides dermestoides on A549 cells. J. Ethnopharmacol., 136, 204-209.

DeFoliart, G.R. (1992): Insects as human food. Gene DeFoliart discusses some nutritional and economic aspects. Crop Prot., 11, 395-399.

DeFoliart, G.R. (1997): An overview of the role of edible insects in preserving biodiversity. Ecol. Food Nutr., 36, 109-132.

EFSA (2012): The European Union summary report on trends and sources of zoonoses, zoonotic agents and foodborne outbreaks in 2010. EFSA J. 10(3), 2597.

EFSA (2015): Scientific Opinion of a risk profile related to production and consumption of insects as food and feed. EFSA J. 13(10), 4257.

EU (2004a): Regulation (EC) No 852/2004 of the European Parliament and of the Council of 29 April 2004 on the hygiene of foodstuffs. Off. J. Eur. Union L139/1

EU (2004b): Regulation (EC) No 853/2004 of the European Parliament and of the Council of 29 April 2004 laying down specific hygiene rules for on the hygiene of foodstuffs. Off. J. Eur. Union L139/55

EU (2015): Regulation (EU) 2015/2283 of the European Parliament and of the Council of EU 25 November 2015 on novel foods, amending Regulation (EU) No 1169/2011 of the European Parliament and of the Council and repealing Regulation (EC) No 258/97 of the European Parliament. Off. J. Eur. Union L327/1

EU (2017): Commission Regulation (EU) 2017/893 of 24 May 2017 amending Annexes I and IV to Regulation (EC) No 999/2001 of the European Parliament and of the Council and Annexes X, XIV and XV to Commission Regulation (EU) No 142/2011 as regards the provisions on processed animal protein. Off. J. Eur. Union L138/92

FAO (2012): Composition database for Biodiversity Version 2, BioFoodComp2. Available at: www.fao.org/infoods/ infoods/tables-and-databases/en/ (Last accessed 2 May 2018)

FDA (1995): The food defect action levels. Levels of natural or unavoidable defects in foods that present no health hazards for humans. Defect levels handbook. U.S. Food and Drug Administration. Available at: https://www. scribd.com/document/198781036/FDA-Handbook-on-Defect-Action (Last accessed 5 May, 2018)

Fellows, P. (2014): Edible insects. -in: Axtell, B. \& Fellows, P. (Eds): Setting up and running a small-scale business producing high-value foods. CTA Publishing, Wageningen, pp. 339-362.

Giaccone, V. (2005): Hygiene and health features of minilivestock. -in: Paoletti, M.G. (Ed.): Ecological implications of minilivestock: Potential of insects, rodents, frogs and snails. Science Publishers, Enfield. pp. 579-598.

GraczyK, T.K., KNIGHT, R. \& TAMANG, L. (2005): Mechanical transmission of human protozoan parasites by insects. Clin. Microbiol. Rev., 18, 128-132.

Handley, M.A., Hall, C., Sanford, E., Diaz, E., Gonzalez-Mendez, E., Drace, K., Wilson, R., Villalobos, M. \& Croughan, M. (2007): Globalization, binational communities, and imported food risks: Results of an outbreak investigation of lead poisoning in Monterey County, California. Am. J. Public Health, 97, 900-906.

Hazeleger, W.C., Bolder, N.M., Beumer, R.R. \& Jacobs-Reitsma, W.F. (2008): Darkling beetles (Alphitobius diaperinus) and their larvae as potential vectors for the transfer of Campylobacter jejuni and Salmonella 
enterica serovar paratyphi B variant Java between successive broiler flocks. Appl. Environ. Microb., 74, $6887-6891$.

Hogan, G.R. \& Razniak, H.G. (1991): Selenium-induced mortality and tissue distribution studies in Tenebrio molitor (Coleoptera: Tenebrionidae). Environ. Entomol., 20, 790-794.

IARC (1993): Some naturally occurring substances: Food items and constituents, heterocyclic aromatic amines and mycotoxins. IARC Monographs on the Evaluation of the Carcinogenic Risk of Chemicals to Humans,Vol. 56. International Agency on Research of Cancer, Lyon, 599 pages. Available at: http://monographs.iarc.fr/ENG/ Monographs/vol56/index.php (Last accessed 5 May, 2018)

IARC (1999): IARC monographs on the evaluation of carcinogenic risks to human. Defect levels handbook 71(8/9). International Agency on the Research on Cancer, Lyon. Available at: http://monographs.iarc.fr/ENG/ Monographs/index.php (Last accessed 5 May, 2018)

JoNGEMA, Y. (2012): List of edible insect species of the world. Wageningen, Laboratory of Entomology, Wageningen University. Available at: www.ent.wur.nl/UK/Edible+insects/Worldwide+species+list/ (Last accessed: 2 May, 2018)

Kinyuru, J.N., Konyole, S.O., Kenj, G.M., Onyango, C.A., Owino, V.O., Owuor, B.O., Estambale, B.B., Fris, H. \& Roos, N. (2012): Identification of traditional foods with public health potential for complementary feeding in Western Kenya. J. Food Res., 1, 148-158

Klunder, H.C., Wolkers-Rooijackers, J., Korpela, J.M. \& Nout, M.J.R. (2012): Microbiological aspects of processing and storage of edible insects. Food Control, 26, 628-631.

Lee, D., Pitetti, R.D. \& Casselbrant, M.L. (1999): Oropharyngeal manifestations of lepidopterism. Arch. Otolaryngol. Head Neck Surg., 125, 50-52.

Lee, C.G., Da Silva, C.A., Lee, J.Y., Hartl, D. \& Elias, J.A. (2008a): Chitin regulation of immune responses: An old molecule with new roles. Curr. Opin. Immunol., 20, 684-689.

LeE, K.P., Simpson, S.J. \& Wilson, K. (2008b): Dietary protein-quality influences melanization and immune function in an insect. Funct. Ecol., 22, 1052-1061.

LupI, O. (2006): Myiasis as a risk factor for prion diseases in humans. J. Eur. Acad. Dermatol., 20, 1037-1045.

Mitsuhashi, J. (2008): The future use of insects as human food. -in: Durst, P.B., Johnson, D.V., LesLie, R.N. \& SHono, K. (Eds): Forest insects as food: Humans bite back. RAP Publication 2010/02. FAO, Chiang Mai, pp. 115-122. Available at: http://www.fao.org/docrep/012/i1380e/i1380e00.pdf (Last accessed 4 May 2108)

Molavi, G.H., Massoud, J., \& Gutierrez, Y. (2006): Human gongylonema infection in Iran. J. Helminthol., 80, 425-428.

Mpuchane, S., Taligoola, H.K. \& Gashe, B.A. (1996): Fungi associates with Imbrasia belina, an edible grasshopper. Botswana Notes and Records, 28, 193-197.

Muzzarelli, R.A.A., Terbojevich, M., Muzzarelli, C., Miliani, M. \& Francescangeli, O. (2001): Partial depolymerization of chitosan with the aid of papain. -in: Muzzarelli, R.A.A. (Ed.): Chitin enzymology. European Chitin Society, Grottammare, pp. 405-414.

NAhrstedt, A. (1988): Cyanogenesis and the role of cyanogenic compounds in insects. Ciba F. Symp., 140, 131150.

Paoletti, M.G., Norberto, L., Damini, R. \& Musumeci, S. (2007): Human gastric juice contains chitinase that can degrade chitin. Ann. Nutr. Metab., 51, 244-251.

Pereira, K.S., Schmidt, F.L., Barbosa, R.L., Guaraldo, A.M., Franco, R.M., Dias, V.L. \& Passos, L.A. (2010): Transmission of chagas disease (American trypanosomiasis) by food. Adv. Food Nutr. Res., 59, 63-85.

Phillips, J.K. \& Burkholder, W.E. (1995): Allergies related to food insect production and consumption. Food Insects Newsl., 8(2), 2-4.

Pimentel, D. (1995): Amounts of pesticides reaching target pests: Environmental impacts and ethics. J. Agr. Environ. Ethic., 8, 17-29.

Pitetti, R.D., Kuspis, D. \& KrenzeloK, E.P. (1999): Caterpillars: An unusual source of ingestion. Pediatr. Emerg. Care, 15, 33-36.

Ramos-Elorduy, J., Pino, J.M., Prado, E.E., Perez, M.A., Otero, J.L. \& de Guevara, O.L. (1997): Nutritional value of edible insects from the state of Oaxaca, Mexico. J. Food Compos. Anal., 10, 142-157.

Ramos-Elorduy, J. (2005): Insects: A hopeful food source. -in: Paoletti, M.G. (Ed.): Ecological implications of minilivestock; Role of rodents, frogs, snails, and insects for sustainable development. Science Publishers, Enfield, pp. 263-291.

Reese, G., Ayuso, R. \& Lehrer, S.B. (1999): Tropomyosin: An invertebrate pan-allergen. Int. Arch. Allergy Imm., $119,247-258$ 
Rumpold, B.A. \& SCHLÜTER, O.K. (2013): Nutritional composition and safety aspects of edible insects. Mol. Nutr. Food Res., 57, 802-823.

SaeEd, T., DagGa, F.A. \& SARAF, M. (1993): Analysis of residual pesticides present in edible locusts captured in Kuwait. Arab Gulf J. Sci. Res., 11, 1-5.

Schabel, H.G. (2008): Forest insects as food: A global review. -in: Durst, P.B., Johnson, D.V., LesLie, R.N. \& SHono, K. (Eds): Forest insects as food: Humans bite back. RAP Publication 2010/02, FAO, Chiang Mai, pp. 19-22. Available at: http://www.fao.org/docrep/012/i1380e/i1380e00.pdf (Last accessed 4 May 2018)

Schlüter, O., Rumpold, B., Holzhauser, T., Roth, A., Vogel, R.F., Quasigroch, W., Vogel, S., Heinz, V., Jäger, H., Bandick, N., Kulling, S., Knorr, D., Steinberg, P. \& Engel, K.-H. (2017): Safety aspects of the production of foods and food ingredients from insects. Mol. Nutr. Food Res., 61(6), 1600520.

Sehgal, R., Bhatti, H.P., Bhasin, D.K., Sood, A.K., NadA, R., Malla, N. \& Singh, K. (2002): Intestinal myiasis due to Musca domestica: A report of two cases. Jpn. J. Infect. Dis., 55(6), 191-193.

Tommaseo-Ponzetta, M. (2005): Insects: Food for human evolution. -in: Paoletti, M.G. (Ed): Ecological implications of minilivestock: Potential of insects, rodents, frogs and snails. Science Publishers, Enfield, pp. $141-161$.

YI, H.-Y., Сhowdhury, M., Huang, Y.-D. \& Yu, X.-Q. (2014): Insect antimicrobial peptides and their applications. Appl. Microbiol. Biot., 98, 5807-5822.

van Huis, A., Van Itterbeeck, J., Klunder, H., Mertens, E., Halloran, A., Muir, G. \& Vantomme, P. (2013): Edible insects: Future prospects for food and feed security. FAO Forestry Paper 171, FAO, Rome, 201 pages. Available at: http://www.fao.org/docrep/018/i3253e/i3253e00.htm (Last accessed 2 May, 2018)

van der Fels-Klerx, H.J., Camenzuli, L., van der Lee, M.K. \& Oonincx, D.G.A.B. (2016): Uptake of cadmium, lead and arsenic by Tenebrio molitor and Hermetia illucens from contaminated substrates. PLoS One. 11(11), e0166186.

VeGA, F.E. \& KAYA, H.K. (2012): Insect pathology. Academic Press, London, 490 pages.

Vega, F.E., Meyling, N.V., Luangsa-Ard, J.J. \& Blackwell, M. (2012): Fungal entomopathogens. -in: Vega, F. \& KAYA, H.K. (Eds): Insect pathology, $2^{\text {nd }}$ ed. Academic Press, San Diego, pp. 171-220.

Vijver, M., Jager, T., Posthuma, L. \& Peinenburg, W. (2003): Metal uptake from soils and soil-sediment mixtures by larvae of Tenebrio molitor L. (Coleoptera). Ecotox. Environ. Safe., 54, 277-289.

WHO (2010): Chagas disease (American trypanosomiasis). Fact sheet nr. 340. Available at: http://www.who.int/ mediacentre/factsheets/fs340/en/ (Last accessed: 3 May 2018) 